\title{
Cinema of The Other Europe
}

\author{
By Ron Holloway
}

Spring 2005 Issue of KINEMA

Dina Iordanova's Cinema of the Other Europe is a book film scholars should have on their shelves for ready reference. Generally speaking, books on cinema written by professors in university film departments are brushed lightly aside by those critics who haunt film festivals and write extensively on directors of choice. And since many of these university editions stem from an in-depth analysis of videotapes and DVDs supplied for classroom courses and film seminars, they are overlooked by the film historian as being a trifle "academic" meaning: tedious, partial, pedantic, even dogmatic. By the same token, the research academician specializing in the sociology, psychology, and semantics of the cinema tend to dismiss "over the top" eulogies by the film critics whose so-called expertise stems from a portfolio of interviews with favourite directors, while paying little attention to the sociopolitical context from which certain key films were formed.

Dina Iordanova's Cinema of the Other Europe - subtitled The Industry and Artistry of East Central European Film - is the exception that should be the rule. On one hand, her book is a comprehensive study of postwar cinema and filmmaking in Poland, Hungary, Czechoslovakia (later the Czech Republic and Slovakia) from 1945 up to 2003. On the other, it is an erudite compendium of the cultural and political forces that melded these national cinematographies into astonishing productive movements under totalitarian governments and kept them alive and resourceful during the trying post-1989 transformations. And through it all she writes with the eye of an appreciative critic who can pinpoint the influential importance of a film or director in a specific country and weigh them in proportion to the national film culture in a neighbouring country.

Take, for instance, Andrzej Wajda's Ashes and Diamonds (Poland, 1958). Czech director Jirí Menzel has often cited that film and its director as a major influence in the development of the Czech New Wave of the 1960s. Cross-cultural references are important and necessary in this specific case - one among many, it should be added.

The singular aspect of Iordanova's study is her focus (almost exclusively) on the cinematographies of "East Central" Europe. Thus the Soviet Union, with its rich tradition of the Russian art film, is left out of the picture almost entirely - despite the enormous impact the cinemas of Andrei Tarkovsky (mentioned three times in the book) and Alexander Sokurov (mentioned just once) had made on the entire European filmcultural scene. East Germany, and the cinema of Konrad Wolf, are also pushed to the side as well, so too the Yugoslav "black film" movement in Southeast Europe.

This telescope approach has its disadvantages, to be sure, for where would Krzysztof Kieslowski's "cinema of moral anxiety" be without the breakthroughs made by Mikhail Romm and Elem Klimov in Soviet cinema? This exclusivity, however, does allow her to dig deep below the surfaces of national cinematographies in Poland and Hungary, Czech Republic and Slovakia. She is thus able to measure the impact of literary influences, social conditions, political realities, historical events, moral or ethical questions, and even surrealist traditions that had inspired key directors to make their best films at the right time and for the right audience. Viewed from this distance, Andrzej Wajda's Man of Marble (1976) and Man of Iron (1981), both milestones in Polish and East Central European cinema, were as much cultural and national manifestos as they were cinematic works of art.

Born in Bulgaria and presently residing in Great Britain, Dina Iordanova was a Reader in Film Studies at the University of Leicester when Cinema of the Other Europe was published in 2003. She currently heads the Chair in Film Studies at the University of St. Andrews in Scotland. She has written extensively on Russian, Balkan, and Eastern European cinema, besides contributing to the Encyclopedia of European Cinema published in 1995 by the British Film Institute. She writes well on Poland's Andrzej Wajda, Krzysztof Zanussi and Krzysztof Kieślowski; on Hungary's István Szabó, Márta Mészáros, and Béla Tarr; and on Czechoslovakia's Miloš Forman, Jiři Menzel, and Vĕra Chytilová - aided by a wealth of videotapes, DVDs, published material, and other Internet sources that are readily available.

But some key young directors are given short shrift: Poland's Dorota Kedzierzawska, Hungary's János Szasz, Slovakia's Martin Šulík, and the Czech Republic's Jan Sverrák and Petr Zelenka, among others. But if I were 
to make a complaint at all, it would be a minor one: for some reason there is a conspicuous absence in the index of a key name - Hungary's Márta Mészáros - although practically a whole chapter is dedicated to her vision of feminist cinema.

Cineastes, critics, and film students are well advised to read and re-read Dina Iordanova's Cinema of the Other Europe, a major research book on the postwar cinematographies of East Central Europe.

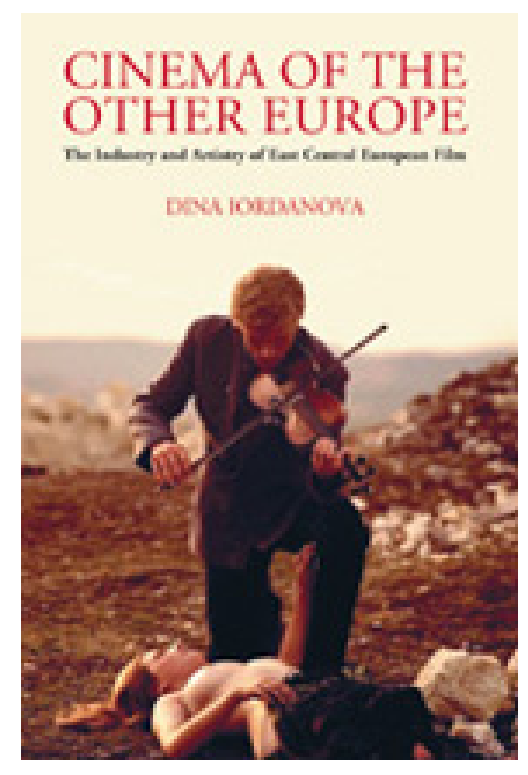

Figure 1: CINEMA OF THE OTHER EUROPE: THE INDUSTRY AND ARTISTRY OF EAST CENTRAL EUROPEAN FILM \ By Dina Iordanova \ London and New York: Wallflower Press, 2003 \ 224pp (UK) 208pp (US) ๆ ISBN: 1903364647 ฯ USD 66.00 (hbk) USD 22.00 (pbk)

\section{Author Information}

Ron HOLLOWAY (1933-2009) was an American critic, film historian, filmmaker and correspondent who adopted Europe as his home in the early fifties and spent much of his life in Berlin. He was an expert on the study of German cinema and against all odds produced, with his wife Dorothea, the journal German Film, keeping us up-to-date with the work of directors, producers and writers and the showing of German films around the world.

In 2007, Ron Holloway and his wife were awarded the Berlinale Camera Award. Ron also received the Bundesverdienstkreuz (German Cross of Merit), Polish Rings, Cannes Gold Medaille, the American Cinema Foundation Award, the Diploma for Support of Russian Cinema and an honorary award from the German Film Critics' Association.

Ron was also a valued contributor to Kinema for the past fifteen years. 